\title{
On the discoloration of silver by boiled eggs
}

\section{Gobley}

To cite this article: M. Gobley (1850) On the discoloration of silver by boiled eggs, Philosophical Magazine Series 3, 37:252, 477-478, DOI: 10.1080/14786445008646664

To link to this article: http://dx.doi.org/10.1080/14786445008646664

册 Published online: 30 Apr 2009.

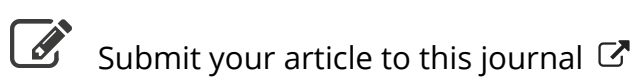

Џll Article views: 2

Q View related articles $₫$ 
because the hydrochloric acid in its turn destroys the hypochlorous acid, and regenerates chlorine: this arrangement will be seen by reversing the two members of the equation,

$$
\begin{aligned}
& 2 \mathrm{Cl}+\mathrm{HO}=\mathrm{ClO}+\mathrm{HCl}, \\
& \mathrm{ClO}+\mathrm{HCl}=2 \mathrm{Cl}+\mathrm{HO} .
\end{aligned}
$$

The hydrochloric and hypochlorous acids can coexist only in the presence of a large quantity of water; the author proved this by direct experiment.

M. Millon is of opinion, that the very simple molecular relation existing between water and hypochlorous acid ought to be extended to the chloride of sulphur, which belongs to this system of sulphuretted hydrogen, of which chlorine has replaced the hydrogen, equivalent for equivalent. It will be seen by this arrangement, that the most chlorinated chloride of sulphur will contain two equal equivalents of chlorine and of sulphur. Thus it will be in vain, as chemists well know, to attempt to combine more than one equivalent of chlorine with one equivalent of sulphur; on the contrary, it is easy to combine several equivalents of sulphur with one equivalent of chlorine. The polysulphurets of hydrogen then come under consideration, and the following symmetries result:-

$$
\begin{aligned}
& \mathrm{HO}, \mathrm{HS}, \mathrm{HS}^{n} \\
& \mathrm{ClO}, \mathrm{ClS}, \mathrm{ClS}^{n} \text {. } \\
& \quad \text { Ann. de Chim. et de Plyys., Aoùt } 1850 .
\end{aligned}
$$

ON THF DISCOLORATION OF SILVER BY BOLLED EGGS. BY

\section{GOBLIY.}

It is observed by the author as a well known fact, that silver, when brought into contact with eggs which have been heated, is blackened; this discoloration is owing to sulphuret of silver. It is usually admitted that this sulphuret is formed by the action of the sulphuretted oils supposed to exist in the yolk of the egg; not having found in this body anything of this nature, M. Gobley thought it would be interesting to examine into the cause of this phrenomenon.

Yolk of egg at common temperatures and when gently heated, does not discolour silver, even by contact of several hours' duration.

Albumen as procured from the egg, does not tarnish silver, but when the temperature is raised, it gives it a brown tint, which is stronger as the heat is greater.

The discoloration of the silver is then due to the sulphur contained in the albumen, and not to that supposed to exist in the oil of the egg; but is the sulphuret formed under these circumstances, the result of the immediate action of the sulphur upon the silver, or by the application of heat do the sulphur and the alkali of the albuminous matter react upon each other, so as to form a substance which is afterwards decomposed by this metal ?

The following experiments induced the author to adopt the second of these opinions:-

1. Paper impregnated with lead, when exposed to the vapour disengaged from the heated albumen, is not sensibly discoloured. 
2. Coagulated white of egg, treated with dilute sulphuric acid, disengages a gas which sensibly discolours lead paper.

3. Coagulated white of egg, brought into contact with a solution of acetate of lead, becomes of a light brownish tint.

The yolk of egg, under the circumstances above described, does not act upon the salts of lead.

Thus the discoloration of silver, by the action of eggs which have been heated, is owing to the reaction of the sulphuret, formed by the combination of the sulphur of the albumen on the soda which it contains.-Journ. de Chém. et de Pharm., Novembre 1850.

ON A TEST FOR PROTEIN COMPOUNDS. BY M. E. MILLON.

The very acid solution which is obtained by dissolving mercury in its weight of nitric acid containing $4 \frac{1}{2}$ equivalents of water, is an extremely sensible reagent for all albuminoid substances, and for a considerable number of secondary products which are connected with it.

This nitromercurial solution communicates a red colour of considerable intensity to these several substances, and it is easy thus to ascertain the presence of 1-10,000dth of albumen, and even a smaller quantity.

To give a direct idea of the delicacy of this reagent, and perhaps of the advantage which may be taken of it in studying the organism of vegetables, the author states that cotton, various kinds of starch, and gum-arabic, when put into contact with it, assume a very distinct rose tint. Urines are almost immediately coloured rose-red; after the nitromercurial solution has been added to them, and the mixture having been heated, the urea is destroyed.

The albumen of the blood and of vegetables, fibrin, casein, gluten, legumin, silk, wool, feathers, horn, the epidermis, gelatin, chondrin, protein, crystallin, the cornea, \&c., are rendered of a more or less intense red colour by this solution.

When protein becomes soluble by the prolonged action of alkaline solutions, or by that of sulphuric acid, the same colour is always produced, but no insoluble matter is obtained; the solution becomes of a deep red colour, without yielding any precipitate.

Xanthoproteic acid, the chlorites of protein, and the oxides of protein derived from them, separate from the preceding products; they are not at all coloured red. 'This reagent exhibits differences which it is very interesting to examine. The author has already ascertained, that, by the action of chlorine upon albumen till the gas ceases to be absorbed, there are formed no less than three substances very distinct from each other.

The nitromercurial solution is prepared by adding to the metal an equal weight of nitric acid, containing $4 \frac{1}{2}$ equivalents of water ; reaction takes place rapidly in the cold; when it has become moderate, the solution is to be very gently heated till the metal is completely dissolved; at this point there are to be added to one volume of the mercurial solution two volumes of water. After some hours the liquid portion is to be decanted from the crystals of nitrate and nitrite of mercury. This solution reacts in the cold on albuminoid 